Pak. j. sci. ind. res. Ser. B: biol. sci. 2020 63B(3) 207-213

\title{
Comparative Efficacy of Bio-Pesticide and Synthetic Agrochemicals on Population Control of Aphids, Helicoverpa armigera, Infestation Control and Yield of Okra
}

\author{
Taimur Ahmad ${ }^{\mathrm{a} *}$, Rasool Khan ${ }^{\mathrm{a}}$, Tariq Nawaz Khattak ${ }^{\mathrm{b}}$, Ihsan Ullah \\ Ayaz Khan and Saleem Khan ${ }^{a}$ \\ ${ }^{a}$ Institute of Chemical Sciences, University of Peshawar, \\ ${ }^{b}$ Nuclear Institute for Food and Agriculture, NIFA, Peshawar \\ (received February 12, 2018; revised February 15, 2019; accepted February 16, 2019)
}

\begin{abstract}
A field study was conducted at village Sardheri, district Charsadda for the year 2017 in order to evaluate the efficacy of bio-insecticides and synthetic agrochemicals against the aphids and Helicoverpa. armigera on Okra. There were eight treatments including control. The highest \% reduction control of aphids after $3^{\text {rd }}$ spray was 91.2 recorded for T6 treatment and T5 was the next superior treatment having a $\%$ reduction of 86.2 . The highest percent reduction in pod damage $(75.5 \%)$ was recorded for T6 after $3^{\text {rd }}$ spray, while T5 was the next superior treatment and the pod borer damage was noted to be $72.2 \%$. T5 yielded the highest mean produce of Okra per plant and was recorded to be $446.3 \mathrm{~g}$. These findings revealed that bio-insecticide can be effectively used to control aphid population as well as the fruit infestation of Okra and improving the yield of Okra. The bio-insecticides can also lower the inputs of residues in the crops and pose least toxicity to non-targeted organism and also readily degradable.
\end{abstract}

Key words: Okra, bio-pesticides, aphids, Helicoverpa armigera

\section{Introduction}

Okra is an important vegetable crop grown throughout the sub-continent. It is widely grown in Pakistan for its food value. Like other agriculture commodities, the Okra plant is attacked by various insect pests. Aphid is one of the notorious sucking pest which causes a great damage to Okra crop. Similarly, H. armigera is a major polyphagous pest and causes a great loss to Okra (Dhaka et al. 2015). Larva of $H$. armigera feed on the flowers and shed them resulting a great yield loss. Larvae $H$. armigera result in pinhole destruction which may cause a disease or rot entry (Sreekanth et al. 2014). It has been investigated that $H$. armigera has developed resistance to a large class of synthetic insecticides in various parts of the world including Asia, Europe, Australia and some parts of Africa (Gandhi et al. 2013; Torres-Villa et al. 2003). The aphids also have developed resistance to almost all the synthetic insecticides. A large number of the synthetic pesticides have been applied for the control of aphids, but their indiscriminate applications have caused a great problems including toxicity to non-targeted organism, resistance development against the pesticides in the insects and high cost etc. (Chavan et al. 2015; Daniels et al. 2009).

\footnotetext{
*Author for correspondence; E-mail: taimurjf@yahoo.com
}

There is a need of alternative pest control strategy which is target specific cost effective and non-toxic to human. Botanicals extracts such as neem oil etc. are good alternative to synthetic pesticides (Damavandian, 2010)

Neem oil has been found to have activity against a wide range of insect pest and show both insecticide and fungicide properties. The neem oil mainly shows antifeeding and deterrent properties and is target specific and only those insect is destroyed which feed on the plant as pest. The action of neem oil is usually slow, and it should be emulsified before its application. Surf or detergent are used as emulsifier for the neem oil. The emulsified neem oil should be prepared when needed and cannot be stored for a long time. An adjuvant has been developed at Nuclear Institute for Food and Agriculture, NIFA, Peshawar. This adjuvant act as emulsifier, spreader and sticker for the pesticide and also increase the action of bio-pesticides. This adjuvant is organic, non-toxic and cost effective and can emulsify $12 \mathrm{~L}$ of the oil. The emulsified neem oil can have a shelf life of two years.

In present study, various synthetic insecticides and the neem oil and white oil pesticides emulsified with NIFA adjuvant have been applied for the control of aphids and H. armigera Okra plant. 


\section{Materials and Methods}

Site of experiment.The experiment was carried out in village Sardheri, district Charsadda for the year 2017. The climate of Charsadda is semi-arid with an annual average rain fall of $450 \mathrm{~mm}$ and mean annual temperature of 24 degrees Celsius.

Design of experiment. The experiment was carried out in randomized complete block design, RCBD, with three replicates. The plot was divided into 32 sub plots and the size of each sub plot was $15 \mathrm{~m}^{2}$. The soil was evenly prepared for seed sowing using a tractor and the weeds were also removed before sowing. Equal amount of DAP and Urea were used as fertilizers during first irrigation. The depth of the seeds was half inch below the earth surface and the space between the seeds was 5 inches. The aphids were monitored from mid-May to mid-July.

Application of the insecticides. There were a total of eight treatments including control with three replicates. The insecticides were used as solution in water in the form of foliar spray. These insecticides were sprayed three times during the experiment. The treatments are designed mentional in Table 1.

Collection of data. The aphid population were determined by simple visual count method. The counting was done at the morning time as the aphids are inactive at morning and they can be easily counted. The population of the aphids was measured by selecting the two upper, one middle and the two lower leaves of ten plants selected randomly in each of the treatments (Singh and Kaushik, 1990) The pre treatment population of aphids was counted one day before the application of insecticides and the post treatment data of aphids was taken one day, seven days and fifteen days after

Table 1. Pesticides treatments and their concentration.

\begin{tabular}{lll}
\hline \hline Treatments & Pesticides & $\begin{array}{l}\text { Concentration of } \\
\text { dose (\%) }\end{array}$ \\
\hline T1 & Bifenthrin & 2 \\
T2 & Emamectin & 2 \\
T3 & Acetamiprid & 2 \\
T4 & Emulsified neem oil & 5 \\
T5 & Neem-white oil & 5 \\
T6 & Imidacloprid & 2 \\
T7 & Chlorpyrifos & 2 \\
T8 & Control & \\
\hline \hline
\end{tabular}

the application. The \% reduction in the population of aphids was calculated after the seventh day of the application of the pesticides in all the treatments. The fruit infestation by $H$. armigera were recorded after $2^{\text {nd }}$ and $3^{\text {rd }}$ spray, as no appreciable damage was reported after first spray. Ten plants per plot were selected and the five pods per plant were selected for studying infested fruits by pod borer. The yield of Okra per plant was determined by randomly selecting 10 plants in each plot. Five times fruit picking was performed for determining the Okra yield per plant. The modified Abbot formula (Fleming and Retnakaran, 1985) for measuring the $\%$ reduction in in the aphid population of all the treatments over control is written as,

$\%$ Reduction $=1-(\mathrm{Ta} / \mathrm{Tb} \times \mathrm{Cb} / \mathrm{Ca}) \times 100$

$\mathrm{Ta}=$ Post treatment aphid population in treatment $\mathrm{Tb}=$ Pre treatment aphid population in the treatment $\mathrm{Cb}=$ Pre treatment aphid population in control $\mathrm{Ca}=$ Post treatment aphid population in control For determining the percent infestation of okra pods, ten plants per plot were selected and the five pods per plant was studied for Helicoverpa armigera infesting the pods.

Statistical analysis. The results obtained were subjected to statistical analysis using statistix 8.1.

\section{Results and Discussion}

The results of efficiency of the all the treatments relating the aphid control are discussed below.

First application of pesticides. The first application of pesticides was done on $5^{\text {th }}$ of May 2015. The attack of aphids was severe and uniform and reached above the economic threshold level. The $24 \mathrm{~h}$ pre treatment data of aphids shows that the number of aphids were almost 36 per five leaves. The post treatment data taken one day after the application of the pesticides shows that there was a decrease in the population of the aphids. The highest reduction of aphids was observed in case of T6 treatment and the mean value of the aphids was 52.3. The other treatments except the control have almost the same population of aphids after one day of application. The maximum number of aphids was recorded with control and was 38 . On the $7^{\text {th }}$ day of the application, there was a considerable reduction in the number of the aphids in all the treatments. The highest mortality was observed in case of imidacloprid treatment with an average aphid population of 16.5 followed by T5 and T4 treatment with a value of 19.5 and 19.66 
respectively. The $\mathrm{T} 1$ and $\mathrm{T} 3$ treatment have nearly the same mean population of aphids with a value of 21.33 and 20.33 respectively.T2 has the highest number of mean aphid population after 7 DAS and was 23.5. The control treatment has a population of 34.5 at $7^{\text {th }}$ DAS. The aphid population increased after 15 DAS and all the seven treatment plots have a higher number of aphids than those recorded after 7 DAS. The lowest population of aphids, 21.5, was recorded for imidocloprid treatment and the highest aphids were found in control having a value of 32.6. The highest percent reduction of aphids was 52.3 for imidacloprid. T4 and T5 have almost the same percent reduction of aphids over control and their values recorded were 42.2 and 42.8 percent respectively as shown in Table 2 .

Second application of pesticides. After the application of $2^{\text {nd }}$ spray, the lowest aphids were recorded for T6 treatment and was 14.8 and the highest was recorded for control and was 34.66. The aphid's population further reduced after seven day of application and the lowest population of aphids was 11.7 for T6 treatment. T5 and T7 have the same aphid's population and was 13.5 for each treatment after 7 days of application. The neem treatment also exhibited a marked decrease in the aphid population and the mean value was recorded to be 14.66 at $7^{\text {th }}$ DAS. The percent reduction in aphid population over control was highest (44.7\%) for T1 treatment after $2^{\text {nd }}$ spray and lowest percent reduction over control was recorded for T3 treatment (31.39). T5 showed next superior result regarding the percent reduction of aphids and was 42.4 percent as shown in Table 3.

Similarly, the Okra pod infestation was also noted after $2^{\text {nd }}$ spray. The pre treatment infestation of pods was recorded one day before the application of the pesticides and there were almost the same infested pods in all the plots except control in which the pods infestation was relatively more. The pod infestation after $6^{\text {th }}$ and $12^{\text {th }}$ day of application of pesticides showed that lowest percent infestation of pods was observed for T6 treatment and was 8.6 and the percent reduction in pod damage over control was highest for this treatment and was 47.8 percent. $\mathrm{T} 2$ treatment was next best treatment after $\mathrm{T} 6$ which recorded the mean infestation of pods of 9.2 percent and the percent reduction of pods over control was 44.2 percent. T5 treatment showed almost the same results as that of $\mathrm{T} 2$ having mean infestation value of 9.4 and the percent reduction in pod damage over control was 43 percent over control. Amongst these treatments, $\mathrm{T} 3$ was the least effective in controlling the pod damage over control and the percent reduction in pod damage was 35.15 over control and the mean percent value for pod damage was 10.7.The highest mean percent pod damage was noted for control and was 16.5 percent as shown in Table 4.

Third application of pesticides. There was a significant decrease in aphid population for all the treatments except control after $3^{\text {rd }}$ spray. The pre treatment population was almost the same for all the treatment except control. The lowest population of aphids at 7 DAS was 1.5 recorded for $\mathrm{T} 6$ treatment and highest was recorded for T3 which was 6.25. T5 was the next superior treatment after $\mathrm{T} 6$ and aphids were 2.4 per five leaves. There was not a significant increase of aphids after $15^{\text {th }}$ DAS. The highest percent reduction of aphids over control was $91.2 \%$ recorded for $\mathrm{T} 6$ after $3^{\text {rd }}$ spray as shown in Table 5 . The lowest $\%$ reduction was recorded for $\mathrm{T} 3$ and was 64.8 percent. T5 and T4 were the next best treatment after T6 and caused a percent reduction of 86.2 and 85.6 respectively.

The pre treatment percent pod infestation was recorded one day before the application of $3^{\text {rd }}$ spray. The mean highest percent pod infestation was 16.11 for control

Table 2. Aphid population and \% reduction over control after $1^{\text {st }}$ spray

\begin{tabular}{lllllll}
\hline \hline \multicolumn{7}{c}{ Aphids population (per 5 leaves) } \\
\hline Treatments & $1 \mathrm{DBS}$ & $1 \mathrm{DAS}$ & $7 \mathrm{DAS}$ & $15 \mathrm{DAS}$ & Mean & \%ROC (7DAS) \\
\hline T1 & $36.5 \pm 5.9 \mathrm{a}$ & $30.6 \pm 5.4 \mathrm{bc}$ & $21.33 \pm 4.1 \mathrm{bc}$ & $28.66 \pm 2.9 \mathrm{ab}$ & 26.8 & 38 \\
T2 & $36.8 \pm 4 \mathrm{a}$ & $32.5 \pm 2.4 \mathrm{ab}$ & $23.5 \pm 2.4 \mathrm{~b}$ & $29 \pm 4.4 \mathrm{ab}$ & 28.3 & 32.25 \\
T3 & $36.33 \pm 5.6 \mathrm{a}$ & $31 \pm 2.6 \mathrm{bc}$ & $20.33 \pm 3.9 \mathrm{bc}$ & $28.8 \pm 3.6 \mathrm{ab}$ & 26.7 & 40.6 \\
T4 & $36 \pm 5.2 \mathrm{a}$ & $30.5 \pm 3.8 \mathrm{bc}$ & $19.66 \pm 3.4 \mathrm{bc}$ & $26.33 \pm 2.2 \mathrm{bc}$ & 25.5 & 42.2 \\
T5 & $36.2 \pm 5.1 \mathrm{a}$ & $29.33 \pm 3.1 \mathrm{bc}$ & $19.5 \pm 3 \mathrm{bc}$ & $25.7 \pm 2.2 \mathrm{bc}$ & 24.8 & 42.8 \\
T6 & $36.7 \pm 3.9 \mathrm{a}$ & $25.33 \pm 2.3 \mathrm{c}$ & $16.5 \pm 2.6 \mathrm{c}$ & $21.5 \pm 3.2 \mathrm{c}$ & 21.1 & 52.3 \\
T7 & $35.8 \pm 4.7 \mathrm{a}$ & $29.6 \pm 2.4 \mathrm{bc}$ & $22.5 \pm 3.5 \mathrm{bc}$ & $26.5 \pm 2.4 \mathrm{bc}$ & 26.2 & 33.3 \\
T8 & $36.6 \pm 4.8 \mathrm{a}$ & $38 \pm 5.4 \mathrm{a}$ & $34.5 \pm 6.5 \mathrm{a}$ & $32.6 \pm 5.3 \mathrm{a}$ & 35 & - \\
\hline \hline
\end{tabular}


Table 3. Aphid population and $\%$ reduction over control after $2^{\text {nd }}$ spray

\begin{tabular}{lllllll}
\hline \hline & \multicolumn{5}{c}{ Aphids population (per 5 leaves) } \\
\hline Treatments & $1 \mathrm{DBS}$ & 1DAS & 7DAS & $15 \mathrm{DAS}$ & Mean & \%ROC (7DAS) \\
\hline T1 & $28.66 \pm 2.9 \mathrm{ab}$ & $22.6 \pm 4.2 \mathrm{bc}$ & $14.33 \pm 2.6 \mathrm{bc}$ & $20.35 \pm 3.3 \mathrm{~b}$ & 19.1 & 44.7 \\
T2 & $29 \pm 4.4 \mathrm{ab}$ & $25.33 \pm 2.2 \mathrm{~b}$ & $16.7 \pm 2.2 \mathrm{bc}$ & $22.66 \pm 4.6 \mathrm{~b}$ & 21.5 & 36.3 \\
T3 & $28.8 \pm 3.6 \mathrm{ab}$ & $23.8 \pm 3.5 \mathrm{~b}$ & $17.88 \pm 3.1 \mathrm{~b}$ & $20.5 \pm 3.2 \mathrm{~b}$ & 20.7 & 31.39 \\
T4 & $26.33 \pm 2.2 \mathrm{bc}$ & $21.5 \pm 3.3 \mathrm{bc}$ & $14.66 \pm 2.6 \mathrm{bc}$ & $20.33 \pm 3.8 \mathrm{~b}$ & 18.8 & 38.4 \\
T5 & $25.7 \pm 2.2 \mathrm{bc}$ & $20.6 \pm 2.8 \mathrm{bc}$ & $13.5 \pm 3.3 \mathrm{bc}$ & $20.2 \pm 4.2 \mathrm{~b}$ & 18.1 & 42.4 \\
T6 & $21.5 \pm 3.2 \mathrm{c}$ & $14.8 \pm 1.7 \mathrm{c}$ & $11.7 \pm 1.9 \mathrm{c}$ & $19.8 \pm 4 \mathrm{~b}$ & 15.4 & 40 \\
T7 & $26.5 \pm 2.4 \mathrm{bc}$ & $20.2 \pm 2.6 \mathrm{bc}$ & $13.5 \pm 3 \mathrm{bc}$ & $20.8 \pm 2.9 \mathrm{~b}$ & 27.2 & 43.7 \\
T8 & $32.6 \pm 5.3 \mathrm{a}$ & $34.66 \pm 11.4 \mathrm{a}$ & $29.5 \pm 5.3 \mathrm{a}$ & $32.7 \pm 6.9 \mathrm{a}$ & 32.2 & - \\
\hline \hline
\end{tabular}

Table 4. Pre treatment and post treatment pod infestation of Okra after $2^{\text {nd }}$ spray

\begin{tabular}{|c|c|c|c|c|c|}
\hline \multicolumn{2}{|c|}{ Pretreatment $\%$ infested pods } & \multicolumn{3}{|c|}{ Post treatment $\%$ infested pods } & \multirow[b]{2}{*}{$\%$ Reduction in pod damage } \\
\hline Treatments & $1 \mathrm{DBS}$ & $6 \mathrm{DAS}$ & $12 \mathrm{DAS}$ & Mean & \\
\hline $\mathrm{T} 1$ & $5.33 \pm 1.2 \mathrm{ab}$ & $10.1 \pm 3.1 \mathrm{~b}$ & $10.33 \pm 1.6 b$ & 10.2 & 38.18 \\
\hline $\mathrm{T} 2$ & $4.8 \pm 2.04 \mathrm{~b}$ & $9.1 \pm 1.4 b$ & $9.3 \pm 2.4 \mathrm{~b}$ & 9.2 & 44.2 \\
\hline $\mathrm{T} 3$ & $5.2 \pm 0.7 \mathrm{~b}$ & $10.8 \pm 2.6 b$ & $10.6 \pm 1.7 \mathrm{~b}$ & 10.7 & 35.15 \\
\hline T4 & $4.5 \pm 1.3 \mathrm{~b}$ & $10.5 \pm 2.4 b$ & $10.3 \pm 1.2 b$ & 10.4 & 37 \\
\hline T5 & $5.2 \pm 1.7 \mathrm{~b}$ & $9.6 \pm 1.6 \mathrm{~b}$ & $9.3 \pm 2.2 b$ & 9.4 & 43 \\
\hline T6 & $4.78 \pm 0.98 \mathrm{~b}$ & $9.2 \pm 1.3 \mathrm{~b}$ & $8.1 \pm 1 b$ & 8.6 & 47.8 \\
\hline $\mathrm{T} 7$ & $5.25 \pm 0.7 \mathrm{ab}$ & $9 \pm 1.3 \mathrm{~b}$ & $10.66 \pm 2.3 b$ & 9.8 & 40.6 \\
\hline T8 & $7.66 \pm 2.1 \mathrm{a}$ & $16.2 \pm 4.2 \mathrm{a}$ & $16.8 \pm 2.5 \mathrm{a}$ & 16.5 & 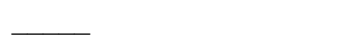 \\
\hline
\end{tabular}

Table 5. Aphid population and $\%$ reduction over control after $3^{\text {rd }}$ spray

\begin{tabular}{lllllll}
\hline \hline \multicolumn{7}{c}{ Aphids population (per 5 leaves) } \\
\hline Treatments & 1 DBS & 1DAS & 7 DAS & 15 DAS & Mean & \%ROC (7DAS) \\
\hline T1 & $20.35 \pm 3.3 \mathrm{~b}$ & $11.66 \pm 2.8 \mathrm{bc}$ & $4.5 \pm 1.8 \mathrm{bc}$ & $6.66 \pm 1.3 \mathrm{bc}$ & 7.6 & 74.4 \\
T2 & $22.66 \pm 4.6 \mathrm{~b}$ & $13.78 \pm 4 \mathrm{~b}$ & $6.1 \pm 1.8 \mathrm{~b}$ & $9.1 \pm 1.7 \mathrm{~b}$ & 9.6 & 68.8 \\
T3 & $20.5 \pm 3.2 \mathrm{~b}$ & $10.2 \pm 2.8 \mathrm{bc}$ & $6.25 \pm 1.1 \mathrm{~b}$ & $8.75 \pm 2.5 \mathrm{~b}$ & 8.4 & 64.8 \\
T4 & $20.33 \pm 3.8 \mathrm{~b}$ & $7.4 \pm 2.5 \mathrm{bc}$ & $2.53 \pm 0.9 \mathrm{~cd}$ & $5.8 \pm 1.5 \mathrm{bc}$ & 5.2 & 85.6 \\
T5 & $20.2 \pm 4.2 \mathrm{~b}$ & $9.4 \mathrm{~d} \pm 1.9 \mathrm{bc}$ & $2.4 \pm 0.6 \mathrm{~cd}$ & $6.3 \pm 2 \mathrm{bc}$ & 6 & 86.2 \\
T6 & $19.8 \pm 4 \mathrm{~b}$ & $4.33 \pm 1.5 \mathrm{c}$ & $1.5 \pm 0.6 \mathrm{~d}$ & $2.33 \pm 0.2 \mathrm{c}$ & 2.72 & 91.2 \\
T7 & $20.8 \pm 2.9 \mathrm{~b}$ & $8.8 \pm 2.1 \mathrm{bc}$ & $3.8 \pm 1.4 \mathrm{bcd}$ & $4.8 \pm 1.5 \mathrm{bc}$ & 5.8 & 78.8 \\
T8 & $32.7 \pm 6.9 \mathrm{a}$ & $30.45 \pm 11.2 \mathrm{a}$ & $28.33 \pm 3.3 \mathrm{a}$ & $27.5 \pm 7.4 \mathrm{a}$ & 28.6 & - \\
\hline \hline
\end{tabular}

and for $\mathrm{T} 1$ toT7 the pre treatment pod infestation was $9.8,8.66,8.2,8.5,8.1,7.7$ and 8.55 respectively. The post treatment infestation damage of 6 DAS and 12 DAS shows that lowest mean pod damage was recorded 4.4 for $\mathrm{T} 6$ treatment.The highest reduction in pod damage over control was also recorded for this treatment and was 75.5 percent. T5 was the next superior treatment after $\mathrm{T} 6$ and the mean pod damage was 5 percent and the percent reduction in pod infestation was 72.2 percent. $\mathrm{T} 2$ showed almost the same results as that of $\mathrm{T} 5 \mathrm{in}$ controlling the pod damage and the mean percent value of pod damage was 5.3, the percent reduction in pod damage was recorded to be 70.5 percent. The other four treatments i.e. T1, T3, T4 and T7 have almost the same mean percent reduction pod damage pod values as depicted in Table 6.

Yield of Okra. The mean yield in gram per plant of five times picking was highest for $\mathrm{T} 5$ treatment and was $446.3 \mathrm{~g}$. T6 has almost the same yield as that of $\mathrm{T} 5$ and was $445.6 \mathrm{~g}$. The control lowest yield was 351.4 $\mathrm{g}$. The highest percent increase in yield was over control 
Table 6. Pre treatment $\&$ post treatment pod infestation of Okra after $3^{\text {rd }}$ spray

\begin{tabular}{llllll}
\hline \hline Pre treatment & \% infested pods & \multicolumn{4}{l}{ Post treatment \% infested pods } \\
\hline Treatments & 1 DBS & 6 DAS & 12 DAS & Mean & \%Reduction in pod damage \\
\hline T1 & $9.8 \pm 1.8 \mathrm{~b}$ & $5.6 \pm 1.1 \mathrm{~b}$ & $5.8 \pm 0.5 \mathrm{~b}$ & 5.7 & 68.3 \\
$\mathrm{~T} 2$ & $8.66 \pm 1.6 \mathrm{~b}$ & $6.1 \pm 0.8 \mathrm{~b}$ & $4.6 \pm 0.8 \mathrm{bc}$ & 5.3 & 70.5 \\
$\mathrm{~T} 3$ & $8.2 \pm 1.3 \mathrm{~b}$ & $6.5 \pm 1.7 \mathrm{~b}$ & $5.66 \pm 1.2 \mathrm{~b}$ & 6 & 66.6 \\
$\mathrm{~T} 4$ & $8.5 \pm 1.3 \mathrm{~b}$ & $6.25 \pm 1.1 \mathrm{~b}$ & $6.3 \pm 1.2 \mathrm{~b}$ & 6.2 & 65.5 \\
$\mathrm{~T} 5$ & $8.1 \pm 1.8 \mathrm{~b}$ & $5.2 \pm 1.5 \mathrm{~b}$ & $4.9 \pm 0.5 \mathrm{bc}$ & 5 & 72.2 \\
$\mathrm{~T} 6$ & $7.7 \pm 2.5 \mathrm{~b}$ & $5.1 \pm 1.2 \mathrm{~b}$ & $3.8 \pm 0.8 \mathrm{c}$ & 4.4 & 75.5 \\
$\mathrm{~T} 7$ & $8.55 \pm 1.8 \mathrm{~b}$ & $6.6 \pm 1.4 \mathrm{~b}$ & $5.2 \pm 1 \mathrm{bc}$ & 5.9 & 67.22 \\
$\mathrm{~T} 8$ & $16.11 \pm 3 \mathrm{a}$ & $17.33 \pm 3.7 \mathrm{a}$ & $18.66 \pm 1.6 \mathrm{a}$ & 18 & \\
\hline \hline
\end{tabular}

observed for T5 treatment and was 27 percent the lowest value 23.93 noted for T1 treatment as shown in Table 7.

The present study, found that imidacloprid resulted in lowest population of aphids after $3^{\text {rd }}$ application of pesticides. These results are in close agreements with the findings of Konar et al. (2013) who used various synthetic pesticides against the sucking aphids on Okra and found imidacloprid which is the most effective insecticide in lowering the aphid population on Okra and observed a percent reduction of $74.5 \%$ in population of aphids over the control. Konar et al. also found that emamactin treatment gave a highest increase in Okra yield over control and observed an increased in yield of $72.27 \mathrm{q} /$ ha over control. Pun et al. (2005) investigated that neem extract greatly lowered the pest attack on Okra and yield was also improved. It is observed that neem extract effectively controlled the population of sucking pest on Okra. Fiaz et al. (2012) used various botanical extracts such as lemon oil, bitter gourd extract, leaf extract of bakain and neem oil having concentration of five percent and found that neem oil showed excellent

Table 7. Mean yield in $\mathrm{g} / \mathrm{plant}$ and $\%$ increase in yield over control

\begin{tabular}{lll}
\hline \hline Treatments & $\begin{array}{l}\text { Mean yield } \\
(\mathrm{g}) \text { per plant }\end{array}$ & $\begin{array}{l}\text { \% increase in } \\
\text { yield over control }\end{array}$ \\
\hline $\mathrm{T} 1$ & $435.3 \mathrm{a}$ & 23.93 \\
$\mathrm{~T} 2$ & $442.5 \mathrm{a}$ & 25.92 \\
$\mathrm{~T} 3$ & $438.5 \mathrm{a}$ & 24.78 \\
$\mathrm{~T} 4$ & $443.7 \mathrm{a}$ & 26.26 \\
$\mathrm{~T} 5$ & $446.3 \mathrm{a}$ & 27 \\
$\mathrm{~T} 6$ & $445.6 \mathrm{a}$ & 26.8 \\
T7 & $441.5 \mathrm{a}$ & 25.6 \\
T8 & $351.4 \mathrm{~b}$ & - \\
\hline \hline
\end{tabular}

repellent and phago-deterrent activities against aphids. Khan et al. (2013) noticed that neem oil was the next superior treatment after lemon oil in lowering the insect pest population of Phenococcus solenopsis on cotton. Misra (2002) reported that population reduction of aphid by imidacloprid is due to its system action. Dhanalakshmi and Mallapur (2008), Bagade and Ambekar (2010) and Ghosh et al.(2009) investigated the efficacy of imidacloprid against the aphids also found that efficacy of this insecticide remained persistent for five to ten days. Mudathir and Basedow (2004) investigated that neem products greatly reduced the insect infestation of Okra pods and also improved the yield of Okra. Praveen and Dhandapani (2001) reported that neem products were highly effective in lowering the aphid population and also resulted in suppressing the infestation caused by fruit borer. Singh and Kumar (2003) reported that neem extracts showed better results of cost benefit ratio over the synthetic endosulfan and reported that neem products were much effective to control the jassid population on Okra. Shah et al. (2013)investigated the effects the neem seed extracts and other botanicals and synthetic emamactin against $H$. armigera on tomato and found that efficacy of neem seed extracts was almost the same as that of synthetic emamactin against pod borer and found low infestation for both neem extracts and emamactin in tomato crop. Hedge (2004) applied the neem seed kernel extracts against $H$. armigera on Okra having concentration of 5 percent and reported that this application resulted in the lowest number of larvae per plant. While Sarode et al. (1995) applied the neem seed kernel extracts against $H$. armigera and found $63.39 \%$ and $53.48 \%$ larval reduction in larval population of $H$. armigera at 7 DAS and 17 DAS. Ansari et al. (2008) applied neem products for the 
control of sucking pest and fruit and shoot borer and investigated a significant reduction in fruit infestation and high yield of Okra was also recorded for neem treatments.

\section{Conclusion}

The current study reveals that imidacloprid was the most effective treatment in controlling the population of aphids and $H$. armigera. The emulsified neem oil and neem oil in combination with white oil belonging to bio-pesticides were the next superior treatments after $3^{\text {rd }}$ application in controlling the pests. These biopesticides are the safe alternatives to synthetic pesticides. Further study is recommended on other crops and pest in order to evaluate the efficacy of neemwhite oil combination.

\section{Acknowledgement}

We are highly thankful to Dr. Tariq Nawaz Khattak for providing chemicals and useful suggestions regarding the data collection.

Conflict of Interest. The authors declare no conflict of interest.

\section{References}

Ansari, N.M.S., Ali, H., Ahmad, T. 2008. Efficacy of multineem and NSKE with insecticides for management of Amrasca biguttula biguttula and Earias vittella on Okra. Annals of Plant Protection Sciences, 16: 17-20.

Bagade, A.S., Ambekar, J.S. 2010. Imidacloprid, the potential pesticide against sucking pests of Okra. Journal of Maharashtra Agriculture University, 35: 116-18.

Chavan, A.P., Patil, S.K., Latake, S. B. 2015. Bioefficacy and economics of insecticide for management of Helicoverpa armigera (Hubner) in chickpea. Annals of Plant Protection Sciences, 23: 27-29.

Damavandian, M.R. 2010. Comparison of current insecticides with mineral oil for the control of Pulvinaria aurantii Comstock in Mazandaran citrus orchards and their efficacy on Phytoseiid mites. Applied Entomology and Phytopathology, 78: 81-97.

Daniels,M., Bale, J.S., Newbury, H.J., Lind, R.J., Pritchard, J. 2009. A sub lethal dose of thiamethoxam causes a reduction in xylem feeding by the bird cherry-oat aphid (Rhopalosiphum padi), which is associated with dehydration and reduced performance. Journal of Insect Physiology, 55: 758-65.

Dhaka, S.S., Singh, G., Yadav, A.,Rai, M., Kumar, A. 2015. Efficacy of novel insecticides against pod borer, Helicoverpa armigera (Hubner) in vegetable pea. Progress in Horticulture, 47: 146-150.

Dhanalakshmi, D.N., Mallapur, C.P. 2008. Evaluation of promising molecules against sucking pests of Okra. Annals of Plant Protection Sciences, 16: 29-32.

Fiaz, M., Hameed, A., Hassan, M., Wakil, W. 2012. Efficacy of plant extracts on some cotton (Gossypium hirsutum) Pests: Amrasca bigutulla bigutulla Ishida and Thrips tabaci Lindeman. Pakistan Journal of Zoology, 44: 277-283.

Fleming, R., Retnakaran, A. 1985. Evaluating single treatment data using Abbot's formula with modification. Journal of Economic Entomology, 78: 1179 .

Gandhi, B. K., Shekharappa, Balikai, R. A. 2013. Bio-efficacy of insecticides in management of Helicoverpa armigera Hubner in Kharif sorghum. Annals of Plant Protection Science, 21: 83-86.

Ghosh, S.K., Mahapatra, G.S.S., Chakraborty, G. 2009. Field efficacy of plant extracts and microbial insecticides against Aphis gossypii Glover infesting Okra Ablemosschus esculentus (L.) Moench. Redia, 92: $249-52$.

Hegde, K.K. 2004. Ecofriendly approaches in the management of Okra fruits borers. M.Sc (Hons.) Thesis. University of Agriculture Sciences, Dharwad, 82.

Khan, A.K.,Saini, S., Singh, K., Aneja, A. 2013. Persistence and residual toxicity of some insecticides against Phenococcus solenopsis on cotton (Gossypium spp.). Indian Journal of Agriculture Sciences, 79: 203-206.

Konar, A., Kiran, A., Duttaray, S.K. 2013. Population dynamics and efficacy of some insecticides against aphid on Okra. Journal of Crop and Weed, 9: 168-171.

Misra, H.P. 2002. Field evaluation of some newer insecticides against aphids (Aphis gosyypii) and jassid (Amarasca biguttula biguttula) on Okra. Indian Journal of Entomology, 64: 80-84. 
Mudathir,M., Basedow, T. 2004. Field experiments on the effects of neem products on pests and yields of Okra Abelmoschus esculentus in the Sudan. Mitteil. Deutsch. Gesellsch. Allgem. Angew. Ent, 14: 407410.

Praveen, P.M., Dhandapani, N. 2001. Eco-friendly management of major pests of Okra (Abelmoschus esculentus (L.) Moench. Journal of Vegetable Crop Production, 7: 3-12.

Pun, K.B., Sabitha, D., Jeyarajan, R. 2005. Management of Okra yellow vein mosaic virus disease and its whitefly vector. Indian Journal of Virology, 16: 32-35.

Sarode, S.V., Jumde, Y.S., Deotale, R.O., Thakre, H.S. 1995. Evaluation for neem seed kernel extract at different concentration of management of Helicoverpa armigera. Indian Journal of Entomology, 57: 385-388.

Shah, J.A., Inayatullah, M., Sohail, K., Shah, S.F., Shah, S., Iqbal, T., Usman, M. 2013. Efficacy of botanical extracts and a chemical pesticide against tomato fruit worm, Helicoverpa armigera Lepidoptera:
Noctuidae). Sarhad Journal of Agriculture, 29: 93-96.

Singh, A.K., Kumar, M. 2003. Efficacy and economics of neem based products against cotton jassid, Amrasca biguttulla Ishida in Okra. Crop Research Hisar, 26: 271-274.

Singh, G., Kaushik, S.K. 1990. Comparative efficacy and sampling techniques for jassid population estimation on Okra, Indian Journal of Ecology, 17: 58-60.

Sreekanth, M., Lakshmi, M.S.M., Koteswar, R.Y. 2014. Bio-efficacy and economics of certain new insecticides against gram pod borer, Helicoverpa armigera (Hubner) infesting pigeonpea (Cajanus cajan L.). International Journal of Plant Animal and Environmental Sciences, 4: 11-15

Torres-Vila, L.M., Rodrý' guez-Molina, M.C., LacasaPlasencia, A. 2003. Testing IPM protocols for Helicoverpa armigera in processing tomato: egg count vs. it-count based damage thresholds using BT or chemical insecticides. Crop Protection, 22: 45-52. 